\title{
Current understanding of the therapeutic benefits of mesenchymal stem cells in acute respiratory distress syndrome
}

\author{
Miquéias Lopes-Pacheco - Chiara Robba • \\ Patricia Rieken Macêdo Rocco 1 - Paolo Pelosi
}

Received: 14 May 2019/Accepted: 27 August 2019/Published online: 4 September 2019

(C) Springer Nature B.V. 2019

\begin{abstract}
The acute respiratory distress syndrome (ARDS) is a multifaceted lung disorder in which no specific therapeutic intervention is able to effectively improve clinical outcomes. Despite an improved understanding of molecular mechanisms and advances in supportive care strategies, ARDS remains associated with high mortality, and survivors usually face longterm morbidity. In recent years, preclinical studies have
\end{abstract}

\footnotetext{
M. Lopes-Pacheco • P. R. M. Rocco ( $\square)$

Laboratory of Pulmonary Investigation, Carlos Chagas Filho Institute of Biophysics, Federal University of Rio de Janeiro, Rio de Janeiro, Brazil

e-mail: prmrocco@biof.ufrj.br

M. Lopes-Pacheco

e-mail: miqueiaslopes@biof.ufrj.br

M. Lopes-Pacheco • P. R. M. Rocco

National Institute of Science and Technology for Regenerative

Medicine, Rio de Janeiro, Brazil

C. Robba $\cdot$ P. Pelosi $(\bowtie)$

Anesthesia and Intensive Care, San Martino Policlinico Hospital, IRCCS for Oncology and Neurosciences, Genoa, Italy

e-mail: paolo.pelosi@unige.it

C. Robba

e-mail: chiara.robba@unige.it

P. Pelosi

Department of Surgical Sciences and Integrated Diagnostics, University of Genoa, Genoa, Italy
}

provided mounting evidence of the potential of mesenchymal stem cell (MSC)-based therapies in lung diseases and critical illnesses. In several models of ARDS, MSCs have been demonstrated to induce antiinflammatory and anti-apoptotic effects, improve epithelial and endothelial cell recovery, and enhance microbial and alveolar fluid clearance, thus resulting in improved lung and distal organ function and survival. Early-stage clinical trials have also demonstrated the safety of MSC administration in patients with ARDS, but further, large-scale investigations are required to assess the safety and efficacy profile of these therapies. In this review, we summarize the main mechanisms whereby MSCs have been shown to exert therapeutic effects in experimental ARDS. We also highlight questions that need to be further elucidated and barriers that must be overcome in order to efficiently translate MSC research into clinical practice.

Keywords Acute respiratory distress syndrome . Biomarkers · Cell therapy · Clinical trials · Mesenchymal stem cells $\cdot$ Lung $\cdot$ Paracrine effects

$\begin{array}{ll}\text { Abbreviations } \\ \text { Ang-1 } & \text { Angiopoietin-1 } \\ \text { ARDS } & \text { Acute respiratory distress syndrome } \\ \text { ATP } & \text { Adenosine triphosphate } \\ \text { ECMO } & \text { Extracorporeal membrane oxygenation } \\ \text { ENaC } & \text { Epithelial sodium channel }\end{array}$




$\begin{array}{ll}\text { EV } & \text { Extracellular vesicle } \\ \text { FGF } & \text { Fibroblast growth factor } \\ \text { HGF } & \text { Hepatocyte growth factor } \\ \text { HLA } & \text { Human leukocyte antigen } \\ \text { IFN } & \text { Interferon } \\ \text { IL } & \text { Interleukin } \\ \text { IL-1RN } & \text { IL-1 receptor antagonist } \\ \text { KGF } & \text { Keratinocyte growth factor } \\ \text { LXA } 4 & \text { Lipoxin A } 4 \\ \text { MIP } & \text { Macrophage inflammatory protein } \\ \text { MMP } & \text { Metalloproteinase } \\ \text { MSCs } & \text { Mesenchymal stem cells } \\ \text { PGE } & \text { Prostaglandin E } \\ \text { TGF- } \beta & \text { Transforming growth factor- } \beta \\ \text { TIMP } & \text { Tissue inhibitor of metalloproteinase } \\ \text { TNF } & \text { Tumor necrosis factor } \\ \text { TSG-6 } & \text { TNF-inducible gene-6 } \\ \text { TLR } & \text { Toll-like receptor } \\ \text { VEGF } & \text { Vascular endothelial growth factor } \\ & \end{array}$

\section{Introduction}

The acute respiratory distress syndrome (ARDS) is a common cause of respiratory failure in critically ill patients. It is characterized by acute and refractory hypoxemia, noncardiogenic pulmonary edema, diffuse alveolar damage, and reduced compliance (or increased lung stiffness) (ARDS Definition Task Force et al. 2012) (Fig. 1). Despite advances in the understanding of ARDS pathophysiology and development of supportive care approaches, such as protective mechanical ventilation, antibiotic and fluid therapies, sedation management, prone positioning, and extracorporeal membrane oxygenation (ECMO), it remains a devastating, lifethreatening disorder associated with a high mortality rate (ranging from 35 to $60 \%$ depending on underlying disease severity) (Bellani et al. 2016; Máca et al. 2017; Papazian et al. 2019). Furthermore, those patients who survive usually face long-term morbidity, which significantly impairs their quality of life (Biehl et al. 2015).

Mounting evidence suggests that cell-based therapies hold therapeutic promise for lung diseases and critical illnesses. Most experimental data have focused on the effects of mesenchymal stem cells (MSCs) from several sources, but some studies have also investigated the therapeutic actions of bone marrow-derived mononuclear cells, endothelial progenitor cells, and others (Li et al. 2013; Silva et al. 2014; Güldner et al. 2015). As no experimental model fully reproduces the pathologic findings observed in human ARDS, a growing number of studies have investigated the efficacy of cell-based therapies across a wide spectrum of experimental models of ARDS (Table 1). Nevertheless, only three, early-stage clinical trials have been completed (Zheng et al. 2014; Wilson et al. 2015; Matthay et al. 2019) and few others are in progress to evaluate the safety of MSC therapy.

In this review, we summarize the main mechanisms by which MSCs have been demonstrated to promote therapeutic benefits in experimental ARDS and shed light on barriers that must be overcome in order to efficiently translate MSC research into clinical practice.

\section{Mesenchymal stem cells}

MSCs were initially isolated from the bone marrow and characterized as an adherent, non-phagocytic, clonogenic, and fibroblast-like cell population (Friedenstein et al. 1968). In 2006, the International Society for Cellular Therapy stablished minimal criteria to define MSCs: (1) they must be plastic-adherent under standard culture conditions; (2) they must express certain cell surface epitopes, such as CD73, CD90, and CD105, and must lack expression of CD11b or CD14, CD34, CD45, CD79, and human leukocyte antigen (HLA)-DR; and (3) they must be able to differentiate into adipocytes, chondroblasts, and osteoblasts in vitro (Dominici et al. 2006). To date, it is known that MSCs can be obtained not only from bone marrow but also from several other tissue sources, including adipose tissue, lung tissue, umbilical cord, and menstrual blood. Furthermore, heterogeneities in gene expression and stability, secretome, and cell surface proteins have been observed in MSCs from different sources, which might impact on their immunomodulatory actions (Ostanin et al. 2011; Nora et al. 2012; Elahi et al. 2016; Heo et al. 2016; Silva et al. 2018a).

Compared to other cell populations, MSCs have demonstrated certain properties that make them more attractive candidates for therapeutic use. They have lower tumorigenic potential than embryonic stem cells and can be rapidly expanded ex vivo, which enables their clinical use in single- or multiple-dose regimens (Weiss et al. 2011). MSCs also exert immunomodulatory actions 
Fig. 1 The pathogenesis cascade of acute respiratory distress syndrome (ARDS) begins with an insult that causes disruption of alveolar-capillary integrity. The alveolar epithelium is the first structure injured in pulmonary ARDS, while endothelial cells are the first structure injured in extrapulmonary ARDS. The loss of alveolar-capillary integrity leads to increased proinflammatory cell infiltration, edema, and tissue remodeling, resulting in impairment of lung function

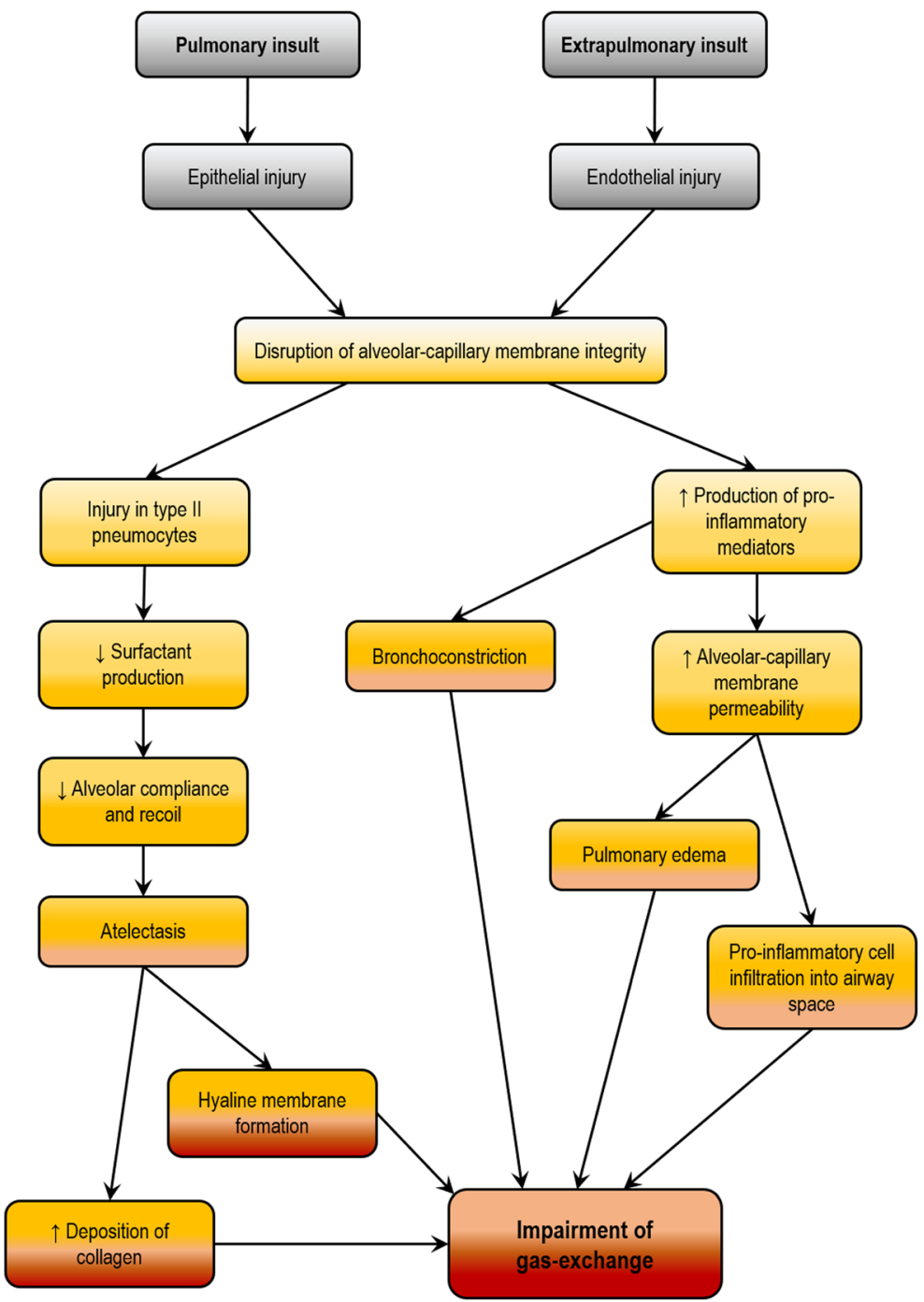

without the need for host-recipient matching, thus allowing their use in either autologous or allogeneic transplantation. MSCs exhibit low expression of HLA type I; HLA type II exists intracellularly but is absent on the cell surface. When cells are preconditioned with interferon (IFN)- $\gamma$, HLA type II can traffic to the cell surface, but MSCs still evade recognition by alloreactive T cells (Le Blanc et al. 2003). Finally, MSCs can detect specifically injured environments and tailor their responses accordingly, which provides an advantage for their use in many diseases (Mathieu and Loboa 2012; Galleu et al. 2017; Leuning et al. 2018; de Castro et al. 2019; Islam et al. 2019).

The mechanisms by which MSCs exert their therapeutic effects are not entirely elucidated and possibly engage multiple signaling pathways. Some postulated mechanisms include cell contact-dependent actions and secretion of paracrine or endocrine factors, which act on nearby cells or travel through the blood to exert their effects. Regardless of whether by contact-dependent or contact-independent mechanisms, MSC administration has been shown to result in anti-inflammatory and antiapoptotic effects, enhanced epithelial and endothelial cell recovery, microbial and alveolar fluid clearance, and, ultimately, reductions in multiple organ injury and mortality (Fig. 2). Notably, although many experimental studies have used vehicle (regular saline or phosphatebuffered saline) as a negative control, no therapeutic benefits were observed when fibroblasts were used as a negative control cell population, indicating that only 
Table 1 Main animal models of acute respiratory distress syndrome used in MSC therapy research

\begin{tabular}{|c|c|c|c|c|}
\hline Etiology & & Model & Disease severity* & Pulmonary features \\
\hline \multirow[t]{3}{*}{$\begin{array}{l}\text { Pulmonary } \\
\text { ARDS }\end{array}$} & \multirow[t]{3}{*}{$\begin{array}{l}\text { Alveolar epithelium } \\
\text { is the primary structure } \\
\text { injured in the lungs }\end{array}$} & LPS i.t. & Mild to moderate & $\begin{array}{l}\text { PMN cell infiltration in intra-alveolar areas, diffuse } \\
\text { alveolar edema, mild changes in epithelial perme- } \\
\text { ability; usually heals with few areas of fibrosis }\end{array}$ \\
\hline & & Live bacteria i.t. & Mild to severe & $\begin{array}{l}\text { PMN cell infiltration in intra-alveolar areas, increased } \\
\text { epithelial permeability, alveolar edema, protein de- } \\
\text { position in the airspaces }\end{array}$ \\
\hline & & Hyperoxia & Mild to moderate & $\begin{array}{l}\text { PMN cell infiltration in vessels and interstitium with } \\
\text { mild infiltration in intra-alveolar areas, presence of } \\
\text { alveolar exudates, vascular congestion; heals with } \\
\text { areas of scarring }\end{array}$ \\
\hline \multirow[t]{3}{*}{$\begin{array}{l}\text { Extrapulmonary } \\
\text { ARDS }\end{array}$} & \multirow[t]{3}{*}{$\begin{array}{l}\text { Vascular endothelium } \\
\text { is the primary structure } \\
\text { injured in the lungs }\end{array}$} & LPS i.p. or i.v. & Mild to moderate & $\begin{array}{l}\text { PMN cell accumulation in capillaries and interstitium } \\
\text { with mild infiltration in intra-alveolar areas, presence } \\
\text { of protein-rich alveolar edema, mild changes in ep- } \\
\text { ithelial permeability; usually heals with few areas of } \\
\text { fibrosis }\end{array}$ \\
\hline & & $\begin{array}{c}\text { Live bacteria } \\
\text { i.p. or i.v. }\end{array}$ & Mild to moderate & $\begin{array}{l}\text { PMN cell sequestration in alveolar capillaries, } \\
\text { interstitial edema, intravascular congestion, mild } \\
\text { protein deposition in the airspaces, no hyaline } \\
\text { membrane formation }\end{array}$ \\
\hline & & CLP & Mild to severe & $\begin{array}{l}\text { PMN cell accumulation in interstitial and alveolar } \\
\text { areas, increased epithelial permeability, alveolar and } \\
\text { interstitial edema, mild hyaline membrane formation }\end{array}$ \\
\hline
\end{tabular}

$C L P$, cecal ligation and puncture; i.p., intraperitoneal; i.t., intratracheal; i.v., intravenous; $L P S$, lipopolysaccharide; $M S C$, mesenchymal stem cell; $P M N$, polymorphonuclear

*The severity can vary depending on animal species and injury protocol (e.g., endotoxin or inoculum dose)

MSCs have the ability to induce such therapeutic benefits (McIntyre et al. 2016).

\section{Therapeutic benefits of MSC therapy in experimental ARDS}

Anti-inflammatory effects

Pathogen- and damage-associated molecular patterns trigger pro-inflammatory responses by resident epithelial and vascular endothelial cells, which results in influx of inflammatory cells and tissue injury. Administration of MSCs either intratracheally or intravenously has been demonstrated to mitigate inflammation by reducing levels of several inflammatory mediators, including interleukin (IL)-1- $\alpha$, IL-1 $\beta$, IL-6, IL-8, IFN- $\gamma$, macrophage inflammatory protein (MIP)-1, MIP-2, and tumor necrosis factor (TNF)- $\alpha$, while also increasing levels of anti-inflammatory and pro-resolution factors, such as IL-1 receptor antagonist (IL-1RN), IL-10, prostaglandin $\mathrm{E}_{2}\left(\mathrm{PGE}_{2}\right)$, lipoxin $\mathrm{A}_{4}\left(\mathrm{LXA}_{4}\right)$, and TNF-inducible gene
(TSG)-6. Such findings were observed in lung tissue homogenates, bronchoalveolar lavage fluid, plasma, and distal organs in distinct models of experimental ARDS (Table 2). A transcription network analysis also revealed that MSC administration may induce downregulation of endotoxin/toll-like receptor (TLR)-innate immune pro-inflammatory responses, while upregulating nuclear factor of activated T cell (NFAT)-related genes, which indicates a shift from innate to adaptive immune responses (dos Santos et al. 2012). Importantly, the anti-inflammatory effects of MSCs have been mostly attributed to paracrine/endocrine mechanisms, as few to no donor-derived cells localize at the host lung tissue after MSC therapy, and MSC-conditioned media has also been shown to decrease pro-inflammatory mediator levels and cell counts in many ARDS models. In this line, certain therapeutic benefits induced by MSCs have been correlated to their ability to produce extracellular vesicles (EVs), which are membrane vesicles ubiquitously secreted by cells. EVs can carry small, messenger, and other RNAs, as well as proteins, lipids, and organelles, which can alter gene 


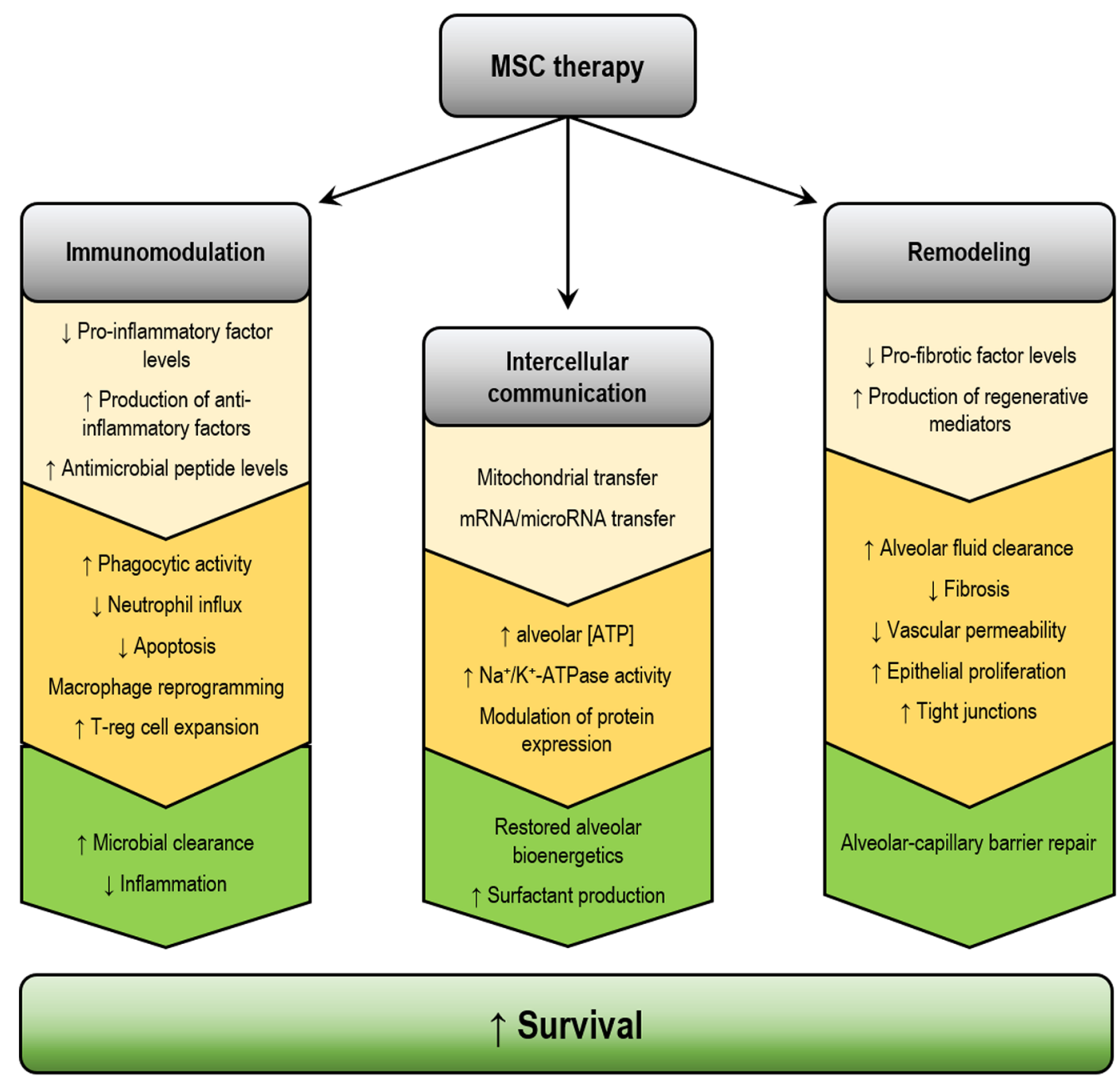

Fig. 2 Summary of therapeutic benefits associated with mesenchymal stem cell therapy in experimental acute respiratory distress syndrome

expression and modulate the behavior of target cells (Yáñez-Mó et al. 2015).

MSCs can induce upregulation of TSG-6, a potent anti-inflammatory mediator that inhibits neutrophilia by suppressing CXCL8-mediated chemotaxis (Danchuk et al. 2011; Dyer et al. 2014). In a model of zymosaninduced peritonitis, macrophage-produced TNF- $\alpha$ stimulated MSCs to produce TSG-6, which acted as a negative feedback loop on macrophage inflammatory signaling (Choi et al. 2011). Knockdown of TSG-6 expression in MSCs has demonstrated to abrogate several antiinflammatory actions of MSC therapy in experimental models of endotoxin-induced lung injury (Danchuk et al. 2011). MSCs also reduced tissue injury by inhibiting formation of neutrophil extracellular traps (Pedrazza et al. 2017). Furthermore, MSC therapy can induce production of IL-1RN to protect lung tissue against bleomycin-induced injury by blocking the production and/or activity of IL- $1 \alpha$ and TNF- $\alpha$ (Ortiz et al. 2007). Repeated administration of cell therapy also prevented disease progression by mitigating expression of IL- $1 \alpha$, IL-1 $\beta$, and IL-1R1, while enhancing expression of IL-1RN, in experimental silicosis-induced lung injury (Lopes-Pacheco et al. 2013).

When exposed to endotoxin or TNF- $\alpha$, MSCs increased production of $\mathrm{PGE}_{2}$, which induced resident macrophage polarization toward the anti-inflammatory M2 phenotype and increased production of IL-10 (Németh et al. 2009). In this context, enhanced production of IL-10 has been correlated with inhibition of rolling, adhesion, and transmigration of neutrophils (Németh et al. 2009) and suppression of effector T cell 


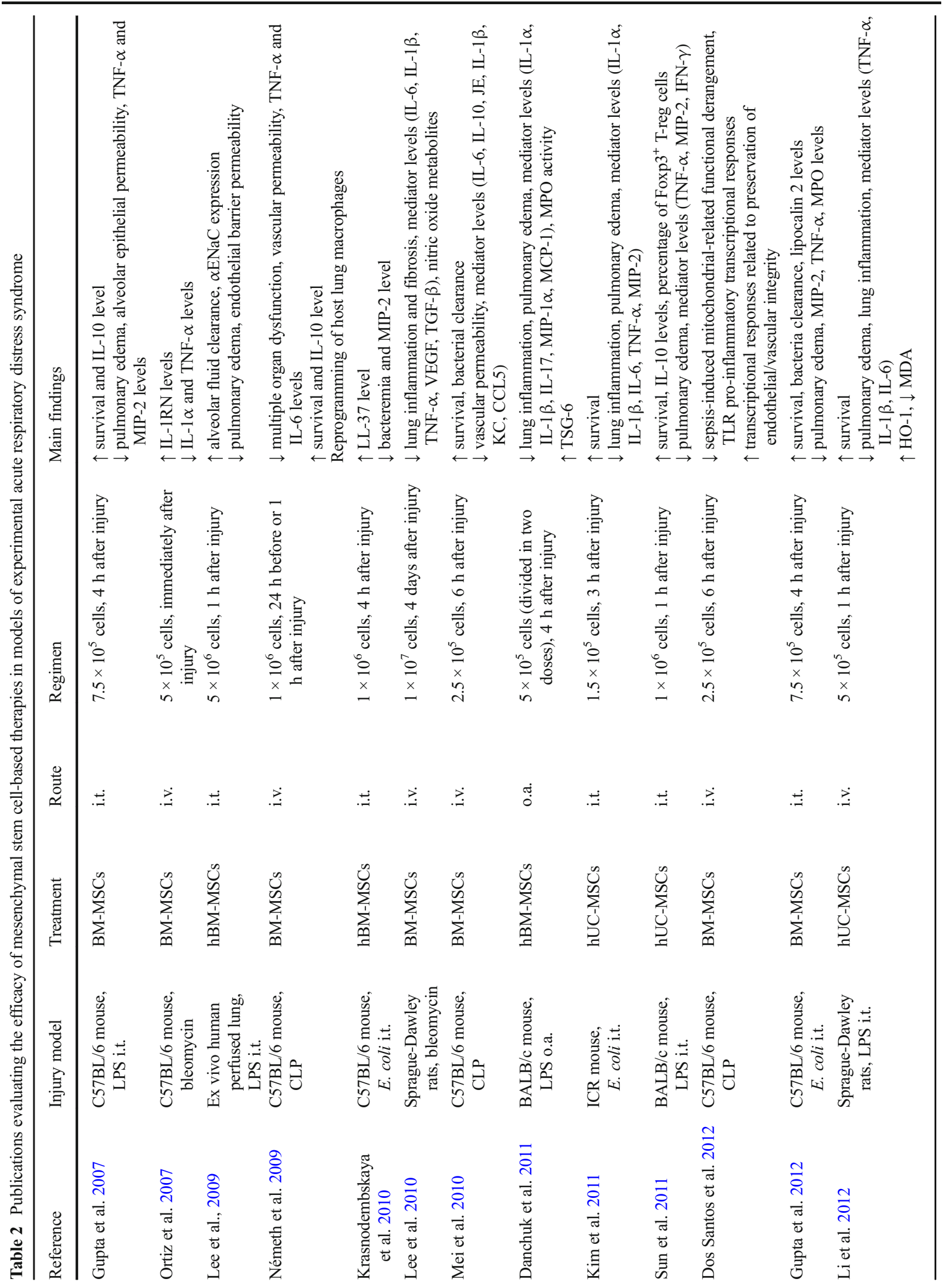




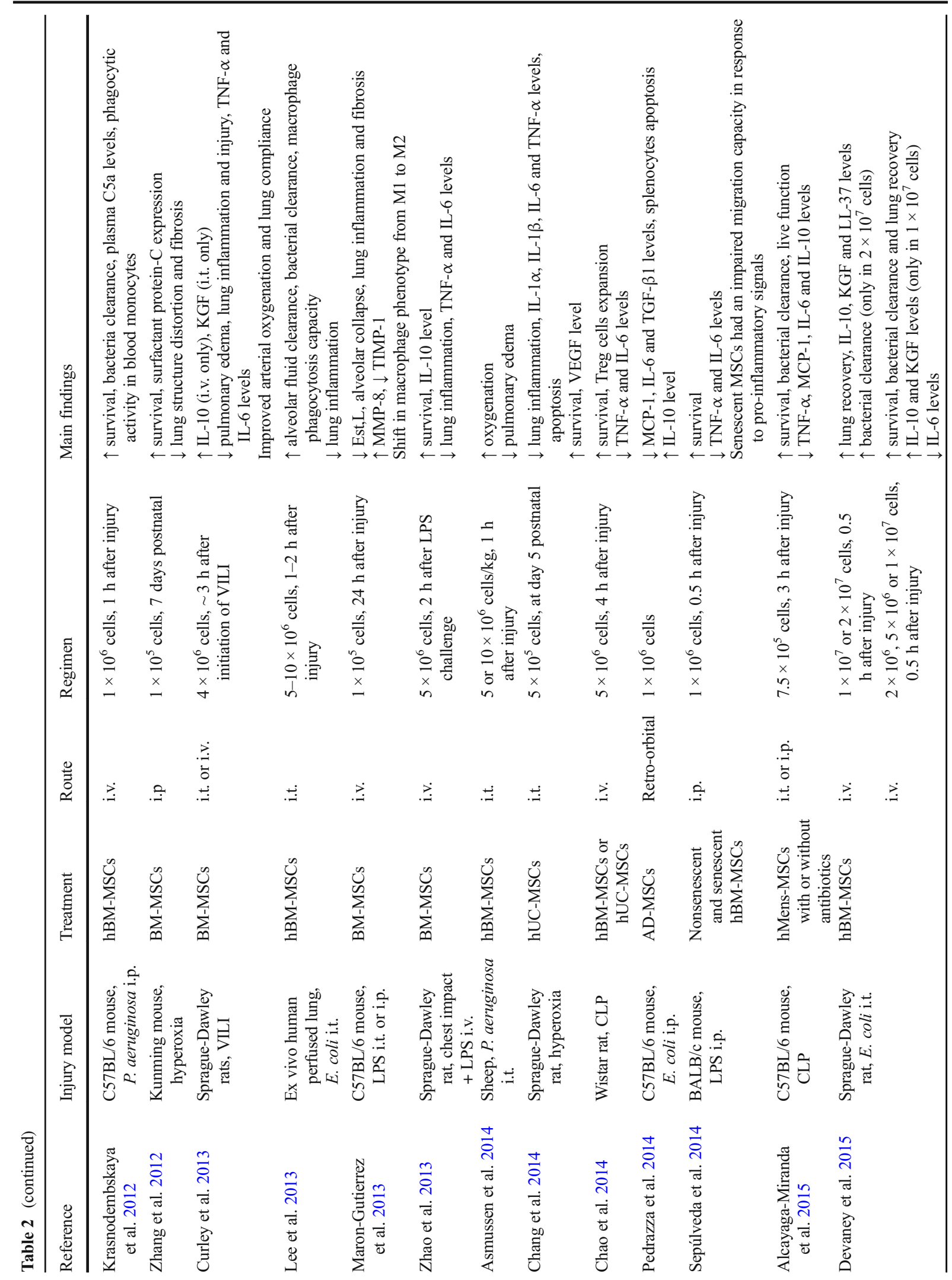




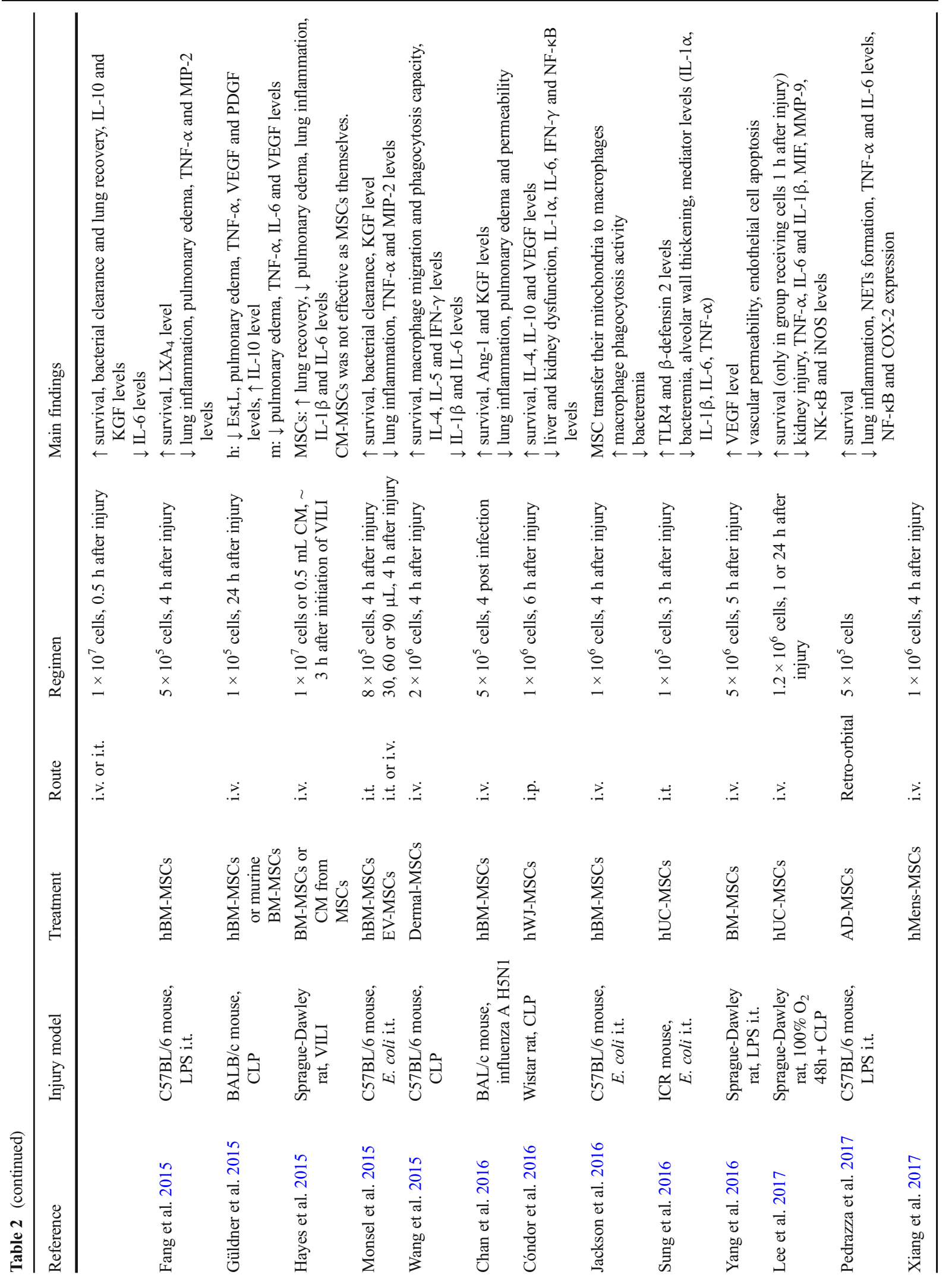




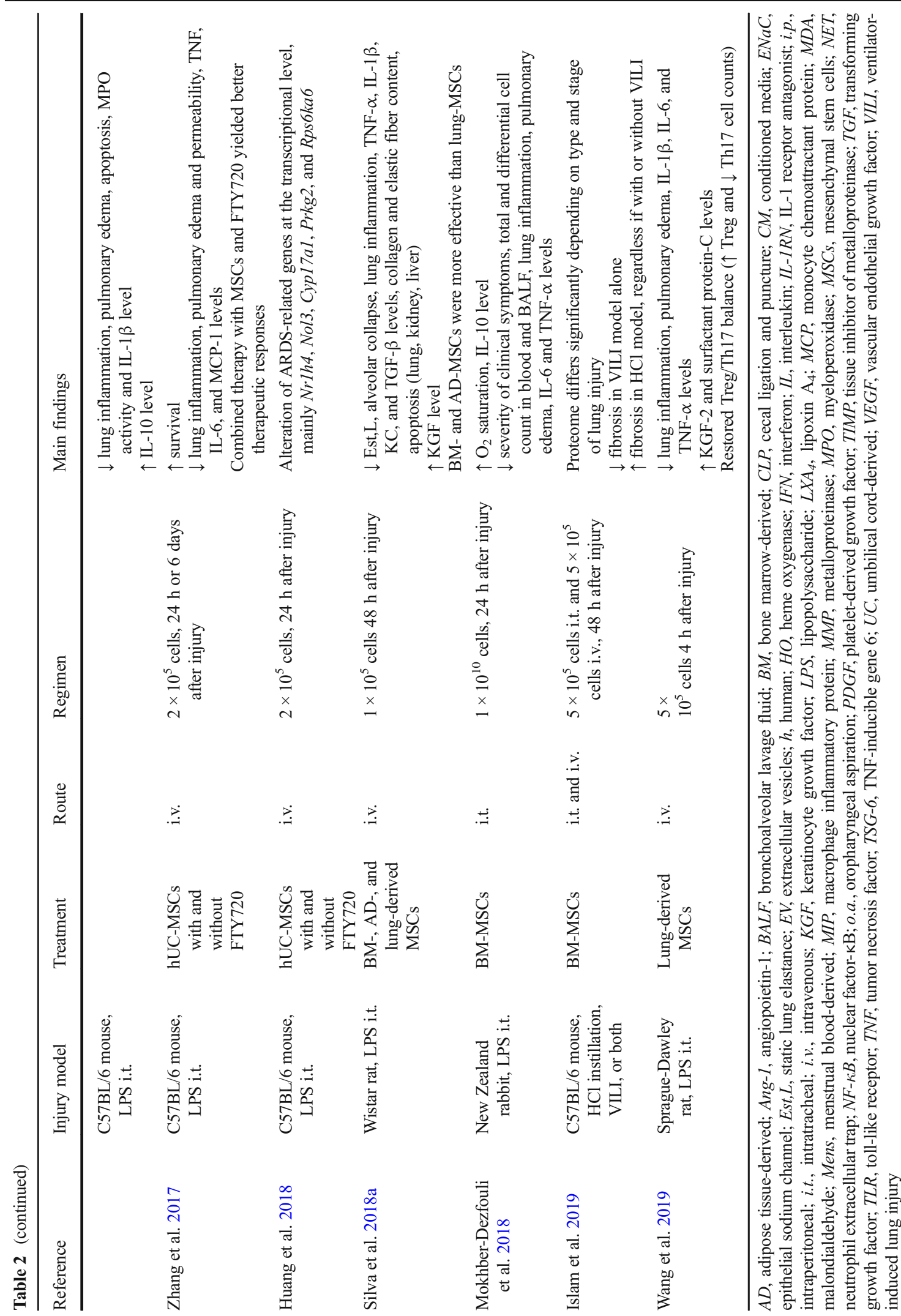


proliferation (Chen et al. 2014), while inducing regulatory T cell expansion (Sun et al. 2011; Chao et al. 2014; Wang et al. 2019) and reprogramming other macrophages into the M2 phenotype (Németh et al. 2009; Vasandan et al. 2016). Although several studies have indicated an increase in IL-10 levels after MSC therapy, others have demonstrated a reduction in the inflammatory process with no change (Gupta et al. 2012; Krasnodembskaya et al. 2012) or even a decrease in IL-10 levels (Mei et al. 2010; Sepúlveda et al. 2014). Similarly, variable effects have been observed regarding IFN- $\gamma$ levels, with studies reporting reduction (Gonzalez-Rey et al. 2009; Sun et al. 2011; Cóndor et al. 2016), no change (Németh et al. 2009; Pedrazza et al. 2014), or even an increase (Wang et al. 2015). In fact, there are several differences among these experimental studies that can explain such heterogeneity: (1) disease severity, etiology, and initial insult; (2) MSC dose, source, and route of administration; (3) timing of therapy (prophylactic or therapeutic) and analysis methods. Although the underlying mechanisms and degree of therapeutic benefit obtained may differ, in most cases, MSCs were nevertheless able to efficiently induce anti-inflammatory effects.

\section{Anti-apoptotic effects}

Apoptosis of both resident and immune cells plays a critical role in ARDS progression, as it leads to recruitment of inflammatory cells and tissue remodeling. Although the mechanisms by which MSC therapy exert anti-apoptotic effects need to be further investigated, MSCs have demonstrated ability to reduce apoptotic cell counts in the lung and distal organs (Pedrazza et al. 2014; Xiang et al. 2017; Silva et al. 2018a; Zhang et al. 2018). MSCs have also been shown to protect alveolar macrophages from endotoxin-induced apoptosis partially by inhibiting the $\mathrm{Wnt} / \beta$-catenin pathway (Li et al. 2015). Increased secretion of keratinocyte growth factor (KGF) after MSC therapy was demonstrated to decrease monocyte apoptosis by protein kinase B phosphorylation (Lee et al. 2013). Furthermore, either MSCs or their conditioned media can protect resting and activated neutrophils in vitro from undergoing apoptosis by cell contact-independent mechanisms (Raffaghello et al. 2008). Several studies have also demonstrated that MSC therapy mitigates TNF- $\alpha$ levels (Kim et al. 2011; Zhao et al. 2013; Güldner et al. 2015), which might contribute to its anti-apoptotic effects, as
TNF- $\alpha$ can induce cell death by activating the Fas/FasL pathway.

Antimicrobial effects

Infection is the most common cause of ARDS, and although MSCs themselves lack phagocytic activity, they can stimulate phagocytosis by host immune cells and production of antimicrobial peptides.

MSC therapy has been demonstrated to significantly reduce bacterial load in animal models of infection induced by Escherichia coli (Cai et al. 2015; Devaney et al. 2015), Pseudomonas aeruginosa (Krasnodembskaya et al. 2012; Asmussen et al. 2014), Staphylococcus aureus (Qian et al. 2016), and polymicrobial sepsis (Gonzalez-Rey et al. 2009; Németh et al. 2009; Alcayaga-Miranda et al. 2015), as well as in an ex vivo perfused human lung model (Lee et al. 2013). Such effects appeared to be mediated by secretion of antimicrobial peptides, including LL-37 (Krasnodembskaya et al. 2010) and lipocalin-2 (Gupta et al. 2012), since antimicrobial actions were abrogated when neutralizing antibodies were used. Secretion of $\beta$-defensin- 2 via TLR4 signaling has also been implicated in MSCinduced bacterial clearance (Sung et al. 2016). Furthermore, MSCs have been shown to reduce bacterial load in vivo by enhancing the phagocytic activity of macrophages (Mei et al. 2010; Lee et al. 2013) and monocytes (Krasnodembskaya et al. 2012). In both in vivo and in vitro models, MSCs also enhanced phagocytic activity of macrophages and monocytes by promoting mitochondrial transfer via tunneling nanotubes, thus resulting in a more effective bacterial clearance (Jackson et al. 2016).

Restoration of epithelial and endothelial cell permeability

Disruption of alveolar-capillary membrane integrity is a hallmark of ARDS and contributes to edema formation and tissue remodeling. MSC therapy has been shown to preserve or restore the alveolar epithelial and vascular endothelial lining, thus reducing lung dysfunction in ARDS models.

In vitro studies have demonstrated that co-culture of endothelial cells with MSCs induced protective actions against inflammatory disruption of barrier function by modulating vascular endothelial cadherin $/ \beta$-catenin signaling (Pati et al. 2011a). MSC therapy also reduced lung endothelial cell permeability in ex vivo perfused 
human lungs injured by either endotoxin or live E. coli, while inhibiting neutrophil influx and enhancing production of fibroblast growth factor (FGF)-7 (Lee et al. 2009a, 2013). Furthermore, in vivo studies demonstrated that MSCs were able to mobilize adherens and tight junction proteins and reduce the binding of inflammatory cells to the endothelium, resulting in preservation of vascular endothelial integrity (Pati et al. 2011b). Controversies persist regarding the impact of MSC therapy on vascular endothelial growth factor (VEGF) levels. Some studies have reported a reduction in VEGF levels after MSC administration when comparing treated vs. untreated injured groups (Lee et al. 2010; Silva et al. 2018a), while other authors have observed an increase (Chang et al. 2014; Yang et al. 2016; Wang et al. 2018a). Further research is needed to better understand the role of VEGF after MSC administration, as it has been correlated with increased vascular endothelial permeability (Lee et al. 2010), angiogenesis and wound healing (Chang et al. 2014; Wang et al. 2018a), and protection of lung vascular endothelium against apoptosis (Yang et al. 2016).

MSCs have been shown to restore epithelial cell protein permeability in human type II pneumocytes exposed to a mix of pro-inflammatory factors (IL-1 $\beta$, IFN- $\gamma$, and TNF- $\alpha$ ) by contact-independent mechanisms and mediated by the secretion of angiopoietin-1 (Ang-1) (Fang et al. 2010). In another study, MSCconditioned media was able to restore sodium transport and preserve epithelial permeability of rat alveolar epithelial cells exposed to a mix of pro-inflammatory factors and hypoxia by increasing levels of IL-1RN and $\mathrm{PGE}_{2}$ (Goolaerts et al. 2014). Furthermore, MSC therapy has been shown to reduce fibrogenesis, while increasing macrophage polarization to the M2 phenotype, which is involved in wound repair and inflammation resolution (Maron-Gutierrez et al. 2013). In this study, MSCs also increased expression of metalloproteinase (MMP)-8 and decreased expression of tissue inhibitor of metalloproteinase (TIMP)-1 (Maron-Gutierrez et al. 2013). Other studies have demonstrated a reduction in lung tissue remodeling (collagen and elastic fiber content) accompanied by decreasing IL- $1 \beta$ and transforming growth factor (TGF)- $\beta$ levels after MSC administration (Silva et al. 2018a).

In an endotoxin-induced lung injury model, MSCs abrogated alveolar leukocytosis and protein leak by contact-dependent mechanisms (Islam et al. 2012). MSCs formed connexin 43-containing gap junctional channels with alveolar cells in vivo, releasing mitochondria-containing microvesicles that restored ATP concentrations, surfactant secretion, and alveolar bioenergetics (Islam et al. 2012). Increased expression of surfactant protein- $\mathrm{C}$ was also observed when injured lung tissue was co-cultured with MSCs and after MSC therapy in hyperoxia-induced lung injury (Zhang et al. 2012).

Increased alveolar fluid clearance and lung recovery

Removal of excessive alveolar and interstitial fluid is crucial for lung recovery and function, since fluid significantly affects surfactant concentration and prevents appropriate gas exchange. Several studies have indicated that MSCs improve alveolar fluid clearance by modulating expression of paracrine factors and function of membrane channels and transporters.

Administration of MSCs or MSC-conditioned media was able to reduce lung water and normalize alveolar fluid clearance in ex vivo perfused human lungs injured by endotoxin or live E. coli (Lee et al. 2009a, 2013). MSCs also normalized alveolar fluid clearance in perfused lungs rejected for transplant, an effect that was significantly reduced when the perfused lung was pretreated with FGF7-neutralizing antibody (McAuley et al. 2014).

In vitro, either co-culture with MSCs or exposure to MSC-conditioned media preserved fluid transport by preventing the reduction in apical expression of $\alpha \mathrm{ENaC}$ subunits. Notably, depletion of FGF7 expression abrogated these therapeutic benefits (Lee et al. 2009a; Goolaerts et al. 2014). Furthermore, in a model of influenza infection-induced lung injury, MSCs prevented impairment of alveolar fluid clearance and protein permeability by enhancing secretion of Ang-1 and $\mathrm{KGF}$ and by preventing downregulation of $\mathrm{Na}^{+} / \mathrm{K}^{+}$ATPase (Chan et al. 2016).

In a model of ventilation-induced lung injury, intratracheally administered MSCs and MSCconditioned media similarly enhanced alveolar fluid clearance, reduced alveolar thickening and inflammation, and restored lung function partly by KGFdependent mechanism (Curley et al. 2013). Nevertheless, compared to MSCs, MSC-conditioned media (administered intravenously) was unable to improve lung edema and inflammation, arterial oxygenation, or static compliance in a subsequent study conducted by the same group (Hayes et al. 2015). Similar findings were 
observed in models of endotoxin-induced lung injury (Silva et al. 2019a).

Improvement of lung and distal organ injury and survival

As ARDS progresses, multiple organ dysfunction can occur, ultimately resulting in increased morbidity and mortality. MSC administration has been demonstrated to protect or even reduce morphological and functional abnormalities in the lung (Maron-Gutierrez et al. 2013; Silva et al. 2018a), kidney (Luo et al. 2014; Cóndor et al. 2016; Silva et al. 2018a), liver (Alcayaga-Miranda et al. 2015; Cóndor et al. 2016; Silva et al. 2018a), heart (Lee et al. 2009b; Weil et al. 2011), spleen (Mei et al. 2010; Pedrazza et al. 2014), and bowel (Gonzalez-Rey et al. 2009; Anderson et al. 2013). These therapeutic effects have a significant impact on the reduction of mortality rate, as observed in many experimental studies (Németh et al. 2009; Mei et al. 2010; Gupta et al. 2012; Chao et al. 2014; Alcayaga-Miranda et al. 2015; Chan et al. 2016; Pedrazza et al. 2017).

\section{Clinical trials of MSC therapy in patients with ARDS}

To date, 13 clinical trials assessing the safety and efficacy of MSC therapy in ARDS patients are registered in the US National Institutes of Health ClinicalTrials.gov platform (https://clinicaltrials.gov) (Table 3). Although all are early-phase clinical studies and are limited by small sample sizes, their major goal is primarily to assess the safety of MSC administration and, secondarily, to assess their efficacy on clinical outcomes, such as respiratory and systemic parameters, inflammation, and hemodynamics. Like most experimental studies, however, these clinical investigations present substantial heterogeneity concerning inclusion and exclusion criteria, length of follow-up, and MSC dose, source, route of administration, and frequency.

The earliest study to assess the safety of MSCs in patients with ARDS was conducted in China (NCT01902082) (Zheng et al. 2014). In this phase I, single-center, randomized, double-blind, placebocontrolled trial, patients received a systemic infusion of allogenic adipose tissue-derived MSCs $\left(1 \times 10^{6}\right.$ cells $\mathrm{kg}^{-1}$ ). Although MSC administration appeared to be safe and well tolerated, impact on clinical outcomes was weak, with no significant differences between the two groups in length of hospital stay, ventilator-free days, or intensive care unit-free days, nor on serum concentration of relevant biomarkers (IL-6, IL-8, and surfactant protein-D) (Zheng et al. 2014). The absence of any evaluation of time- and dose-response relationships for MSC therapy as well as the short follow-up period (28 days) are major limitations of this clinical study.

Another study assessing the safety of MSCs in ARDS patients was conducted in the USA (NCT01775774) (Wilson et al. 2015). In this phase I, multicenter, open-label, dose-escalation clinical study, patients with moderate to severe ARDS received a single intravenous infusion of allogeneic bone marrowderived MSCs $\left(1,5\right.$, or, $10 \times 10^{6}$ cells kg $\left.{ }^{-1}\right)$. Although no significant differences were observed in concentrations of measured biomarkers (IL-6, IL-8, ANGPT2, and AGER), all MSC dose levels were well tolerated, with no infusion-related adverse events. The same research group conducted a subsequent clinical trial with the highest MSC dose $\left(10 \times 10^{6}\right.$ cells kg $\left.{ }^{-1}\right)$, as it was associated with a more favorable trend in lung injury score and sequential organ failure assessment score compared to lower doses (Wilson et al. 2015). In this subsequent phase IIa, multicenter, randomized, doubleblind, placebo-controlled trial (NCT02097641) (Matthay et al. 2019), patients with moderate to severe ARDS received a single intravenous infusion of allogeneic bone marrow-derived MSCs $\left(10 \times 10^{6}\right.$ cells kg-1 $)$. No patient experienced any of the predefined MSCrelated hemodynamic and respiratory adverse events. A trend for improvement in oxygenation index, albeit not significant, was observed in the patients that received MSCs. Furthermore, concentrations of angiopoietin-2 in plasma were significantly reduced in MSC recipients, indicating a reduction in endothelial injury (Matthay et al. 2019).

MSCs have also been tested in compassionate-use settings. In a Swedish case report, two patients with severe, refractory ARDS who failed to improve after standard life support measures received systemic administration of allogeneic bone marrow-derived MSCs $(2 \times$ $10^{6}$ cells $\mathrm{kg}^{-1}$ ) obtained from a healthy volunteer (Simonson et al. 2015). Both patients recovered from hemodynamic, respiratory, and multiple organ failure. These outcomes were associated with a reduction in several pulmonary and systemic biomarkers of inflammation (Simonson et al. 2015). 
Table 3 Clinical trials evaluating the safety and efficacy of mesenchymal stem cell-based therapies in patients with acute respiratory distress syndrome

\begin{tabular}{|c|c|c|c|c|c|c|}
\hline ClinicalTrials.gov ID & Country & Phase & Treatment & Dose, frequency, and route & Patients enrolled & Follow-up \\
\hline \multicolumn{7}{|l|}{ Completed } \\
\hline $\begin{array}{l}\text { NCT01775774 } \\
\text { (Wilson et al. 2015) }\end{array}$ & USA & I & BM-MSCs & $\begin{array}{l}1,5 \text {, or } 10 \times 10^{6} \text { cells kg }{ }^{-1}, \text { i.v., } \\
\text { single dose }\end{array}$ & $9(3 / 3 / 3)$ & 12 months \\
\hline $\begin{array}{l}\text { NCT01902082 } \\
\quad \text { (Zheng et al. 2014) }\end{array}$ & China & I & AD-MSCs & $1 \times 10^{6}$ cells kg ${ }^{-1}$, i.v., single dose & $12(6 / 6)$ & 28 days \\
\hline $\begin{array}{l}\text { NCT02097641 } \\
\text { (Matthay et al. 2019) }\end{array}$ & USA & IIa & BM-MSCs & $10 \times 10^{6}$ cells $\mathrm{kg}^{-1}$, i.v., single dose & $60(40 / 20)$ & 12 months \\
\hline \multicolumn{7}{|l|}{ Ongoing } \\
\hline NCT02095444 & China & $\mathrm{I} / \mathrm{II}$ & Mens-MSCs & $\begin{array}{l}10 \times 10^{6} \text { cells } \mathrm{kg}^{-1}, \text { i.v., twice a } \\
\text { week for } 2 \text { weeks }\end{array}$ & 20 & 14 days \\
\hline NCT02112500 & Korea & II & BM-MSCs & i.v. & 10 & 28 days \\
\hline NCT02215811 & Sweden & I & BM-MSCs & Not reported & 10 & 12 months \\
\hline NCT02444455 & China & $\mathrm{I} / \mathrm{II}$ & UC-MSCs & $\begin{array}{l}5 \times 10^{5} \text { cells } \mathrm{kg}^{-1} \text {, i.v., once daily } \\
\quad \text { for } 3 \text { days }\end{array}$ & 20 & 14 days \\
\hline NCT02611609 & UK/USA & $\mathrm{I} / \mathrm{II}$ & MultiStem & Not reported & 36 & 12 months \\
\hline NCT02804945 & USA & II & BM-MSCs & $3 \times 10^{6}$ cells kg ${ }^{-1}$, i.v., single dose & 20 & 60 days \\
\hline NCT03042143 & UK & $\mathrm{I} / \mathrm{II}$ & UC-MSCs & $\begin{array}{l}1,5 \text {, or } 10 \times 10^{6} \text { cells kg }{ }^{-1}, \text { i.v., } \\
\quad \text { single dose }\end{array}$ & 75 & 28 days \\
\hline NCT03552848 & China & Not reported & UC-MSCs & $\begin{array}{l}1 \times 10^{6} \text { cells, i.v., once } \\
\text { every } 4 \text { days for four times }\end{array}$ & 15 & 24 months \\
\hline NCT03608592 & China & I & UC-MSCs & $60 \times 10^{6}$ cells, i.v., single dose & 12 & 28 days \\
\hline NCT03818854 & USA & $\mathrm{IIb}$ & BM-MSCs & $10 \times 10^{6}$ cells kg ${ }^{-1}$, i.v., single dose & $120(60 / 60)$ & 60 days \\
\hline
\end{tabular}

MSCs, mesenchymal stromal cells; $A D$, adipose tissue-derived; $B M$, bone marrow-derived; Mens, menstrual blood-derived; $U C$, umbilical cord-derived; i.v., intravenous

\section{Barriers and future directions for MSC therapy in ARDS}

MSC therapy holds promise for the treatment of ARDS for many reasons, as described above. Despite important advances, further research is needed to elucidate several unanswered questions, including the optimal MSC source and dose, route of administration, and frequency (single vs. multiple-dose regimen). Moreover, in many experimental protocols, MSCs were administered before, at the time of, or only a few hours after disease induction; these models fail to take into account the time course of lung and distal organ injury and, therefore, do not resemble the clinical situation.

Although bone marrow has been the most common source used to obtain MSCs (McIntyre et al. 2016), an invasive harvesting procedure is required, and these cells have limited availability. Furthermore, experimental ARDS has been shown to modify the profile of the bone marrow cell population, affecting their immunomodulatory effects and limiting their potential use for autologous transplantation (Silva et al. 2014; Antebi et al. 2018). MSCs from different sources have been intensively investigated, as these cells exhibit differences in gene expression and stability, secretome, and cell surface proteins, which may impact on their survival and regenerative properties (Ostanin et al. 2011; Nora et al. 2012; Elahi et al. 2016; Heo et al. 2016). However, few studies have comparatively evaluated the effects of MSCs from different sources (Nystedt et al. 2013; Chao et al. 2014; Silva et al. 2018a), and whether cells from any one source may provide superior therapeutic responses remains unclear. In addition, cell dosing has meaningful clinical relevance and remains under-investigated, as clinical trials conducted to date have focused on safety, with efficacy as a secondary assessment. MSCs have been administered as a single dose ranging from $5 \times 10^{4}$ to $3.6 \times 10^{7}$ cells in experimental models (McIntyre et al. 2016). From a translational perspective, this range in a 25 -g mouse would correspond to $2 \times 10^{6}$ to $1.44 \times 10^{9}$ cells kg ${ }^{-1}$ (or 150 million to 108 billion cells for a $75-\mathrm{kg}$ human). Such quantities are technically and operationally challenging, and administration of high doses of MSCs is associated with several safety 
concerns. To date, $1 \times 10^{7}$ cells kg ${ }^{-1}$ is the highest dose ever used in clinical studies. As in pharmacological research, determination of the therapeutic window and index for MSC therapies is a critical step that should be further characterized in experimental studies to ensure that the greatest therapeutic benefits can be achieved without resulting in side effects in the clinical setting.

MSC administration has been performed by either local or systemic routes in different experimental models. While local administration (e.g., intratracheal) delivers cells directly to the site of injury, systemic administration (e.g., intravenous) allows wide distribution throughout the body. However, MSCs administered intravenously are subjected to the pulmonary first-pass effect (Fischer et al. 2009), which results in significant retention of cells. In fact, this effect may offer an advantage for lung tissue repair. Although ongoing clinical trials and most number of experimental studies have used the intravenous route (McIntyre et al. 2016), therapeutic responses were similar in the few studies that compared different routes for MSC delivery in animal models (Curley et al. 2013; Alcayaga-Miranda et al. 2015; Devaney et al. 2015). Importantly, ECMO has become an increasingly common therapeutic modality for patients with severe ARDS (Bellani et al. 2016; Papazian et al. 2019). In an ex vivo model, MSCs administered intravascularly were found to adhere to membrane oxygenator fibers during ECMO, resulting in a significant reduction of flow through the circuit (Millar et al. 2019). Further investigations should be performed with alternative routes of administration, such as intrabronchial, to identify which would be a viable option for this clinical situation. Finally, most experimental studies have focused on short-term effects of MSC therapy; evaluation of long-term effects has been comparatively neglected. Although a single dose of MSCs has been shown to result in therapeutic responses, more than one dose may be required to induce a more efficient tissue repair or even to maintain benefits, as observed in animal models of elastase-induced emphysema and silicosis (Lopes-Pacheco et al. 2013; Poggio et al. 2018).

As the surrounding environment can have a significant impact on MSC phenotype and behavior (Mathieu and Loboa 2012; Galleu et al. 2017; Leuning et al. 2018; de Castro et al. 2019; Islam et al. 2019), recent experimental studies have employed different methods to enhance the therapeutic actions of MSCs (Silva et al. 2018b) (Table 4). Under hypoxic conditions, MSCs have been shown to upregulate expression of genes related to pro-survival, anti-apoptotic, antioxidant signaling, resulting in reduction of fibrosis and expression of pro-inflammatory mediators in a model of bleomycin-induced lung injury (Lan et al. 2015). In experimental sepsis, MSC preconditioning with poly (I:C), a TLR3 ligand, inhibited expression of miR-143 and increased expression of cyclooxygenase-2, resulting in increased $\mathrm{PGE}_{2}$ production and macrophage antiinflammatory actions (Zhao et al. 2014). Compared to naïve MSCs, eicosapentaenoic acid-preconditioned MSCs induced further reduction in lung inflammation and remodeling as well as in lung and distal organ injury, thus resulting in greater improvement in severity score and survival in CLP-induced experimental sepsis (Silva et al. 2019b). Other studies have also demonstrated enhancement of therapeutic effects by inducing overexpression of certain genes by MSCs, including Ang-1 (Mei et al. 2007), IL-33 antagonist soluble IL-1R1 (MartínezGonzález et al. 2013), IL-10 (Wang et al. 2018b; Jerkic et al. 2019), Nrf2 (Zhang et al. 2018), and HGF (Meng et al. 2019). As the degree of therapeutic outcomes can differ depending on disease severity, etiology, and primary insult, different preconditioning approaches may provide a more appropriate MSC therapy according to the disease features of each patient, thus driving more effective therapeutic and regenerative responses.

Despite tremendous progress in investigating cellbased therapy in ARDS, the safety of MSC therapy has been only demonstrated in early-stage clinical studies with a relatively small number of patients. Therefore, the safety and efficacy of MSC therapy has yet to be demonstrated in large-scale clinical trials. Furthermore, if they ever prove to be an efficient therapy, MSCs must still be available within few hours, in enough quantity, and obtained in an affordable manner from a wellregulated and controlled production process if they are to become a viable therapy for patients with acute or critical illnesses, including ARDS (Ginty et al. 2011). Several barriers in the process of standardization, scalability, manufacturing, distribution, cost, and regulation, which still preclude the efficient, routine use of MSC therapy, have been discussed elsewhere (Heathman et al. 2015; Isasi et al. 2016).

\section{Conclusion}

MSC-based therapies constitute promising strategies for the treatment of ARDS, given their demonstrated 


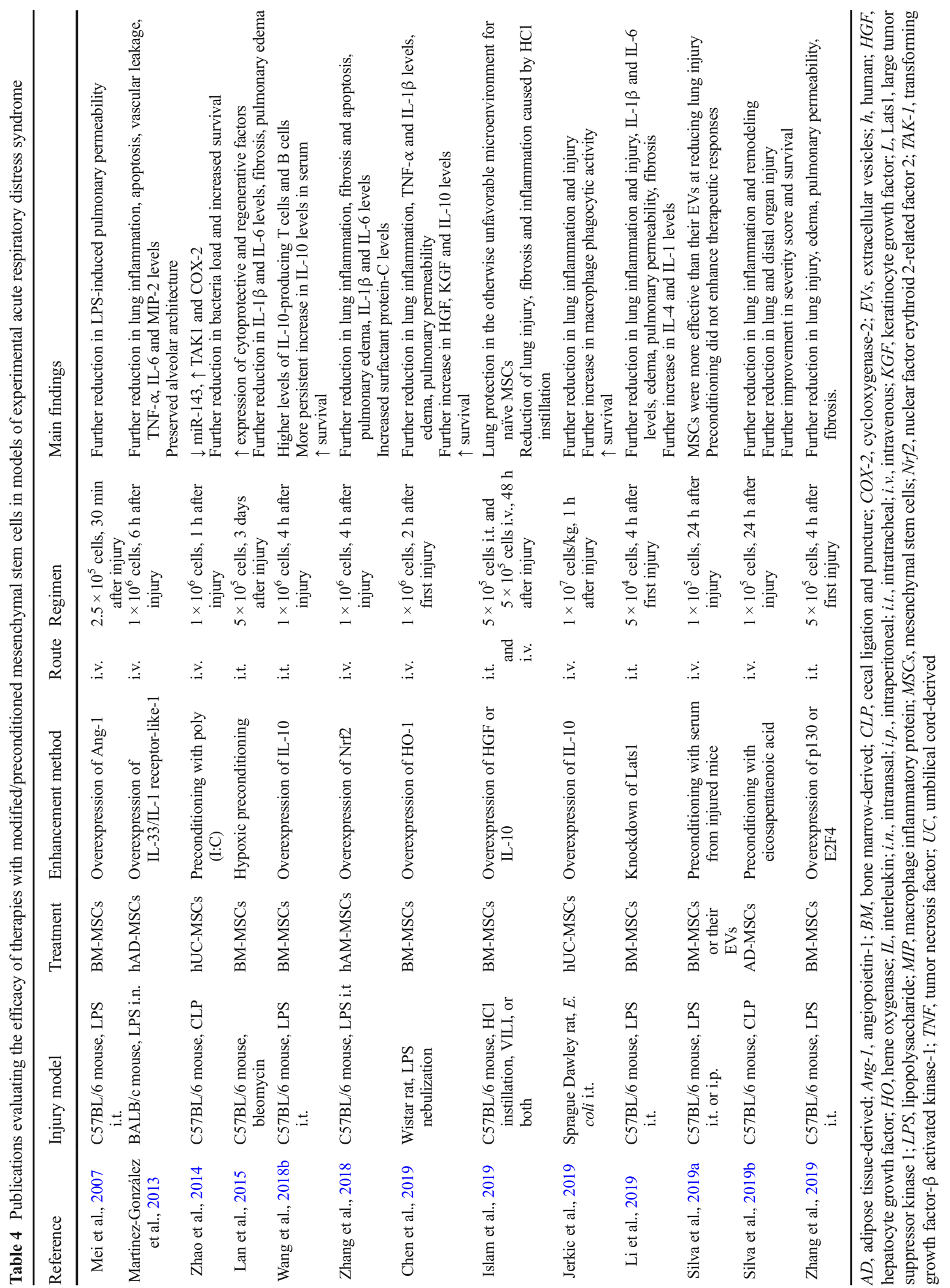


therapeutic benefits: anti-inflammatory and antiapoptotic effects, enhanced epithelial and endothelial cell recovery, microbial and alveolar fluid clearance, and improvements in lung and distal organ injury and survival. The benefits of MSC-based therapies appeared to be induced by complex, well-orchestrated signaling pathways rather than by any one (or few) mechanisms. Key mechanisms of action include secretion of paracrine and endocrine factors as well as transfer of cellular contents via extracellular vesicles or cell-to-cell contact. Despite the progress reviewed herein, many questions have yet to be answered before the therapeutic impact of MSCs can be maximized. The possibility of enhancing the benefits of MSCs by preconditioning methods has brought novel opportunities that should be further explored. Safety results from phase I and II clinical trials are encouraging, but the safety and efficacy profile has yet to be proven in large-scale trials. In an ideal clinical scenario, MSCs would be promptly available and obtained through well-standardized procedures, but some barriers still pose challenges to the feasibility of MSC therapy.

Funding information This study was supported by the Brazilian Council for Scientific and Technological Development (CNPq), the Rio de Janeiro State Research Foundation (FAPERJ), the Department of Science and Technology (DECIT)/Brazilian Ministry of Health, and the National Institute of Science and Technology for Regenerative Medicine (INCT-Regenera).

\section{Compliance with ethical standards}

Conflict of interest The authors declare that they have no conflict of interest.

\section{References}

Alcayaga-Miranda F, Cuenca J, Martin A, Contreras L, Figueroa FE, Khoury M. Combination of therapy of menstrual derived mesenchymal stem cells and antibiotics ameliorates survival in sepsis. Stem Cell Res Ther. 2015;6:199.

Anderson P, Souza-Moreira L, Morell M, Caro M, O’Valle F, Gonzalez-Rey E, et al. Adipose-derived mesenchymal stromal cells induce immunomodulatory macrophages which protect from experimental colitis and sepsis. Gut. 2013;62(8):1131-41.

Antebi B, Walker KP 3rd, Mohammadipoor A, et al. The effect of acute respiratory distress syndrome on bone marrow-derived mesenchymal stem cells. Stem Cell Res Ther. 2018;9(1):251. https://doi.org/10.1186/s13287-018-0981-3.
ARDS Definition Tasks Force, Ranieri VM, Rubenfeld GD, et al. Acute respiratory distress syndrome: the Berlin definition. JAMA. 2012;307(23):2526-33.

Asmussen S, Ito H, Traber DL, Lee JW, Cox RA, Hawkins HK, et al. Human mesenchymal stem cells reduced the severity of acute lung injury in a sheep model of bacterial pneumonia. Thorax. 2014;69(9):819-25.

Bellani G, Laffey JG, Pham T, Fan E, Brochard L, Esteban A, et al. Epidemiology, patterns of care, and mortality of patients with acute respiratory distress syndrome in intensive care units in 50 countries. JAMA. 2016;315(8):788-800.

Biehl M, Kashyap R, Ahmed AH, Reriani MK, Ofoma UR, Wilson GA, et al. Six-month quality-of-life and functional status of acute respiratory syndrome survivors compared to patients at risk: a population-based study. Crit Care. 2015;19: 356.

Cai SX, Liu AR, Chen S, He HL, Chen QH, Xu JY, et al. Activation of $\mathrm{Wnt} / \beta$-catenin signaling promotes mesenchymal stem cells to repair injured alveolar epithelium induced by lipopolysaccharide in mice. Stem Cell Res Ther. 2015;6: 65.

Chan MC, Kuok DI, Leung CY, et al. Human mesenchymal stromal cells reduce influenza A H5N1-associated acute lung injury in vitro and in vivo. Proc Natl Acad Sci U S A. 2016;113(13):3621-6.

Chang YS, Ahn SY, Jeon HB, Sung DK, Kim ES, Sung SI, et al. Critical role of vascular endothelial growth factor secreted by mesenchymal stem cells in hyperoxic lung injury. Am J Respir Cell Mol Biol. 2014;51(3):391-9.

Chao YH, Wu HP, Wu KH, Tsai YG, Peng CT, Lin KC, et al. An increase in $\mathrm{CD} 3+\mathrm{CD} 4+\mathrm{CD} 25+$ regulatory $\mathrm{T}$ cells after administration of umbilical cord-derived mesenchymal stem cells during sepsis. PLoS One. 2014;9(10):e110338.

Chen PM, Liu KJ, Hsu PJ, Wei CF, Bai CH, Ho LJ, et al. Induction of immunomodulatory monocytes by human mesenchymal stem cell-derived hepatocyte growth factors through ERK1/2. J Leukoc Biol. 2014;96(2):295-303.

Chen X, Wu S, Tang L, Ma L, Wang F, Feng H, et al. Mesenchymal stem cells overexpressing heme oxygenase-1 ameliorates lipopolysaccharide-induced acute lung injury in rats. J Cell Physiol. 2019;234(5):7301-19. https://doi. org/10.1002/jcp. 27488 .

Choi H, Lee RH, Bazhanov N, Oh JY, Prockop DJ. Antiinflammatory protein TSG-6 secreted by activated MSCs attenates zymosan-induced mouse peritonitis by decreasing TLR2/NF-KB signaling in resident macrophages. Blood. 2011;118(2):330-8. https://doi.org/10.1182/blood-2010-12327353.

Cóndor JM, Rodrigues CE, Sousa Moreira RD, et al. Treatment with human Wharton's jelly-derived mesenchymal stem cells attenuates sepsis-induced kidney injury, liver injury, and endothelial dysfunction. Stem Cells Transl Med. 2016;5(8): 1048-57.

Curley GF, Ansari B, Hayes M, Devaney J, Masterson C, Ryan A, et al. Effects of intratracheal mesenchymal stromal cell therapy during recovery and resolution after ventilator-induced lung injury. Anesthesiology. 2013;118(4):924-32.

Danchuk S, Ylostalo JH, Hossain F, Sorge R, Ramsey A, Bonvillain RW, et al. Human multipotent stromal cells attenuate lipopolysaccharide-induced acute lung injury in mice via 
secretion of tumor necrosis factor- $\alpha$-induced protein 6 . Stem Cell Res Ther. 2011;2(3):27.

De Castro LL, Lopes-Pacheco M, Weiss DJ, et al. Current understanding of the immunosuppressive properties of mesenchymal stromal cells. J Mol Med (Berl). 2019;97(5):605-18. https://doi.org/10.1007/s00109-019-01776-y.

Devaney J, Horie S, Masterson C, Elliman S, Barry F, O'Brien T, et al. Human mesenchymal stromal cells decrease the severity of acute lung injury induced by E. coli in the rat. Thorax. 2015;70(7):625-35.

Dominici M, Le Blanc K, Mueller I, et al. Minimal criterial for defining multipotent mesenchymal stromal cells. The International Society for Cellular Therapy position statement. Cytotherapy. 2006;8(4):315-7.

Dos Santos CC, Murthy S, Hu P, et al. Network analysis of transcriptional responses induced by mesenchymal stem cell treatment of experimental sepsis. Am J Pathol. 2012;181(5): 1681-92.

Dyer DP, Thomson JM, Hermant A, Jowitt TA, Handel TM, Proudfoot AEI, et al. TSG-6 inhibits neutrophil migration via direct interaction with the chemokine CXCL8. J Immunol. 2014;192(5):2177-85.

Elahi KC, Klein G, Avci-Adali M, et al. Human mesenchymal stromal cells from different sources diverge in their expression of cell surface proteins and display distinct differentiation patterns. Stem Cells Int. 2016;2016:5646384.

Fang X, Neyrinck AP, Matthay MA, Lee JW. Allogeneic human mesenchymal stem cells restore epithelial protein permeability in cultured human alveolar type II cells by secretion of angiopoietin-1. J Biol Chem. 2010;285(34):26211-22.

Fang X, Abbott J, Cheng L, Colby JK, Lee JW, Levy BD, et al. Human mesenchymal stem (stromal) cells promote the resolution of acute lung injury in part through lipoxin A4. J Immunol. 2015;195(3):875-81.

Fischer UM, Harting MT, Jimenez F, Monzon-Posadas WO, Xue $\mathrm{H}$, Savitz SI, et al. Pulmonary passage is a obstacle for intravenous stem cell delivery: the pulmonary first-pass effect. Stem Cells Dev. 2009;18(5):683-93. https://doi. org/10.1089/scd.2008.0253.

Friedenstein AJ, Petrakova KV, Kurolesova AI, et al. Heterotopic of bone marrow. Analysis of precursor cells for osteogenic and hematopoietic tissues. Transplantation. 1968;6(2):23047.

Galleu A, Riffo-Vasquez Y, Trento C, et al. Apoptosis in mesenchymal stromal cells induces in vivo recipient-mediated immunomodulation. Sci Transl Med. 2017;9(416): eaam7828.

Ginty PJ, Rayment EA, Hourd P, Williams DJ. Regenerative medicine, resource and regulation: lessons learned from the REMEDI project. Regen Med. 2011;6(2):241-53.

Gonzalez-Rey E, Anderson P, González MA, et al. Human adult stem cells derived from adipose tissue protect against experimental colitis and sepsis. Gut. 2009;58(7):929-39.

Goolaerts A, Pellan-Randrianarison N, Larghero J, Vanneaux V, Uzunhan Y, Gille T, et al. Conditioned media from mesenchymal stromal cells restore sodium transport and preserve epithelial permeability in an in vitro model of acute alveolar injury. Am J Physiol Lung Cell Mol Physiol. 2014;306(11): L975-85.

Güldner A, Maron-Gutierrez T, Abreu SC, Xisto DG, Senegaglia AC, Barcelos PRS, et al. Expanded endothelial progenitor cells mitigate lung injury in septic mice. Stem Cell Res Ther. 2015;6:230.

Gupta N, Su X, Popov B, Lee JW, Serikov V, Matthay MA. Intrapulmonary delivery of bone marrow-derived mesenchymal stem cells improves survival and attenuates endotoxin-induced acute lung injury in mice. J Immunol. 2007;179(3):1855-63.

Gupta N, Krasnodembskaya A, Kapetanaki M, Mouded M, Tan X, Serikov V, et al. Mesenchymal stem cells enhance survival and bacterial clearance in murine Escherichia coli pneumonia. Thorax. 2012;67(6):533-9.

Hayes M, Curley GF, Masterson C, Devaney J, O'Toole D, Laffey JG. Mesenchymal stromal cells are more effective than the MSC secretome in diminishing injury and enhancing recovery following ventilator induced lung injury. Intensive Care Med Exp. 2015;3(1):29.

Heathman TR, Nienow AW, McCall MJ, et al. The translation of cell-based therapies: clinical landscape and manufacturing challenges. Regen Med. 2015;10(1):49-64.

Heo JS, Choi Y, Kim HS, et al. Comparison of molecular profiles of human mesenchymal stem cells derived from bone marrow, umbilical cord blood, placenta and adipose tissue. Int $\mathrm{J}$ Mol Med. 2016;37(1):115-25.

Huang Z, Liu H, Zhang X, Wen G, Zhu C, Zhao Y, et al. Transcriptomic analysis of lung tissues after hUC-MSCs and FTY720 treatment of lipopolysaccharide-induced acute lung injury in mouse models. Int Immunopharmacol. 2018;63:26-34.

Isasi R, Rahimzadeh, Charlebois K. Uncertainty and innovation: understanding the role of cell-based manufacturing facilities in shaping regulatory and commercialization environments. Appl Transl Genom. 2016;11:27-39.

Islam MN, Das SR, Emin MT, Wei M, Sun L, Westphalen K, et al. Mitochondrial transfer from bone-marrow-derived stromal cells to pulmonary alveoli protects against acute lung injury. Nat Med. 2012;18(5):759-65.

Islam D, Huang Y, Fanelli V, Delsedime L, Wu S, Khang J, et al. Identification and modulation of microenvironment is crucial for effective mesenchymal stromal cell therapy in acute lung injury. Am J Respir Crit Care Med. 2019;199(10):1214-24.

Jackson MV, Morrison TJ, Doherty DF, McAuley DF, Matthay MA, Kissenpfennig A, et al. Mitochondrial transfer via tunneling nanotubes is an important mechanism by which mesenchymal stem cells enhance macrophage phagocytosis in the in vivo and in vitro models of ARDS. Stem Cells. 2016;34(8):2210-23.

Jerkic M, Materson C, Ormesher L, et al. "Overexpression of IL10 Enhances the Efficacy of Human Umbilical-Cord-Derived Mesenchymal Stromal Cells in E. coli Pneumosepsis." J Clin Med. 2019;8(6):847.

Kim ES, Chang YS, Choi SJ, Kim JK, Yoo HS, Ahn SY, et al. Intratracheal transplantation of human umbilical cord bloodderived mesenchymal stem cells attenuates Escherichia coliinduced acute lung injury in mice. Respir Res. 2011;12:108.

Krasnodembskaya A, Song Y, Fang X, Gupta N, Serikov V, Lee JW, et al. Antibacterial effect of human mesenchymal stem cells is mediated in part from secretion of the antimicrobial peptide LL-37. Stem Cells. 2010;28(12):2229-38.

Krasnodembskaya A, Samaran G, Song Y, et al. Human mesenchymal stem cells reduce mortality and bacteremia in gramnegative sepsis in mice by enhancing the phagocytic activity 
of blood monocytes. Am J Physiol Lung Cell Mol Physiol. 2012;302(10):L1003-13.

Lan YW, Choo KB, Chen CM, Hung TH, Chen YB, Hsieh CH, et al. Hypoxia-preconditioned mesenchymal stem cells attenuate bleomycin-induced pulmonary fibrosis. Stem Cell Res Ther. 2015;6:97.

Le Blanc K, Tammik C, Rosendahl K, et al. HLA expression and immunologic properties of differentiated and undifferentiated mesenchymal stem cells. Exp Hematol. 2003;31(10):890-6.

Lee JW, Fang X, Gupta N, Serikov V, Matthay MA. Allogeneic human mesenchymal stem cells for treatment of E. coli endotoxin-induced acute lung injury in the ex vivo perfused human lung. Proc Natl Acad Sci U S A. 2009a;106(38): 16357-62.

Lee RH, Pulin AA, Seo MJ, Kota DJ, Ylostalo J, Larson BL, et al. Intravenous hMSCs improve myocardial infarction in mice because cells embolized in lung are activated to secrete the anti-inflammatory protein TSG-6. Cell Stem Cell. 2009b;5(1):54-63.

Lee SH, Jang AS, Kim YE, Cha JY, Kim TH, Jung S, et al. Modulation of cytokine and nitric oxide by mesenchymal stem cell transfer in lung injury/fibrosis. Respir Res. 2010;11: 16.

Lee JW, Krasnodembskaya A, McKenna DH, et al. Therapeutic effects of human mesenchymal stem cell in ex vivo human lung injured with live bacteria. Am J Respir Crit Care Med. 2013;187(7):751-60.

Lee FY, Chen KH, Wallace CG, et al. Xenogeneic human umbilical cord-derived mesenchymal stem cells reduce mortality in rats with acute respiratory distress syndrome complicated by sepsis. Oncotarget. 2017;8(28):45626-42.

Leuning DG, Beijer NRM, du Fossé NA, Vermeulen S, Lievers E, van Kooten C, et al. The cytokine secretion profile of mesenchymal stromal cells is determined by surface structure of the microenvironment. Sci Rep. 2018;8(1):7716.

Li J, Li D, Liu X, Tang S, Wei F. Human umbilical cord mesenchymal stem cells reduce systemic inflammation and attenuate LPS-induced acute lung injury in rats. J Inflamm (Lond). 2012;9(1):33.

Li H, Qiang Y, Wang L, et al. Repair of lipopolysaccharideinduced acute lung injury in mice by endothelial progenitor cells, alone and in combination with simvastatin. Chest. 2013;114(3):876-86.

Li B, Zhang H, Zeng M, He W, Li M, Huang X, et al. Bone marrow mesenchymal stem cells protect alveolar macrophages from lipopolysaccharide-induced apoptosis partially by inhibiting the Wnt $/ \beta$-catenin pathway. Cell Biol Int. 2015;39(2):192-200.

Li L, Dong L, Zhang J, Gao F, Hui J, Yan J. Mesenchymal stem cells with downregulated Hippo signaling attenuates lung injury in mice with lipopolysaccharide-induced acute respiratory distress syndrome. Int J Mol Med. 2019;43(3):124152. https://doi.org/10.3892/ijmm.2018.4047.

Lopes-Pacheco M, Xisto DG, Ornellas FM, Antunes MA, Abreu SC, Rocco PRM, et al. Repeated administration of bone marrow-derived cells prevents disease progression in experimental silicosis. Cell Physiol Biochem. 2013;32(6):168194.

Luo CJ, Zhang FJ, Zhang L, Geng YQ, Li QG, Hong Q, et al. Mesenchymal stem cells ameliorate sepsis-associated acute kidney injury in mice. Shock. 2014;41(2):123-9.
Máca J, Jor O, Holub M, et al. Past and present ARDS mortality rates: a systematic review. Respir Care. 2017;62(1):113.122.

Maron-Gutierrez T, Silva JD, Asensi KD, Bakker-Abreu I, Shan Y, Diaz BL, et al. Effects of mesenchymal stem cell therapy on the time course of pulmonary remodeling depend on the etiology of lung injury in mice. Crit Care Med. 2013;41(11):e319-33.

Martínez-González I, Roca O, Masclans JR, Moreno R, Salcedo MT, Baekelandt V, et al. Human mesenchymal stem cells overexpressing the IL-33 antagonist soluble IL-1 receptorlike-1 attenuate endotoxin-induced acute lung injury. Am J Respir Cell Mol Biol. 2013;49(4):552-62.

Mathieu PS, Loboa EG. Cytoskeletal and focal adhesion influences on mesenchymal stem cell shape, mechanical properties, and differentiation down osteogenic, adipogenic and chondrogenic pathways. Tissue Eng Part B Rev. 2012;18(6): 436-44.

Matthay MA, Calfee CS, Zhuo H, Thompson BT, Wilson JG, Levitt JE, et al. Treatment with allogeneic mesenchymal stromal cells for moderate to severe acute respiratory distress syndrome (STARS study): a randomised phase 2a safety trial. Lancet Respir Med. 2019;7(2):154-62.

McAuley DF, Curley GF, Hamid UI, et al. Clinical grade allogeneic human mesenchymal stem cells restore alveolar fluid clearance in human lungs rejected for transplantation. Am J Physiol Lung Cell Mol Physiol. 2014;306(9):L809-15.

McIntyre LA, Moher D, Fergusson DA, et al. Efficacy of mesenchymal stromal cell therapy or acute lung injury in preclinical animal models: a systematic review. PLoS One. 2016;11(1): e0147170.

Mei SH, McCarter SD, Deng Y, et al. Prevention of LPS-induced acute lung injury in mice by mesenchymal stem cell overexpressing angiopoietin 1. PLoS Med. 2007;4(9):e269.

Mei SH, Haitsma JJ, dos Santos CC, et al. Mesenchymal stem cells reduce inflammation while enhancing bacterial clearance and improving survival in sepsis. Am J Respir Crit Care Med. 2010;182(8):1047-57.

Meng SS, Guo FM, Zhang XW, Chang W, Peng F, Qiu HB, et al. mTOR/STAT-3 pathway mediates mesenchymal stem cellsecreted hepatocyte growth factor protective effects against lipopolysaccharide-induced vascular endothelial barrier dysfunction and apoptosis. J Cell Biochem. 2019;120(3):363750.

Millar JE, von Bahr V, Malfertheiner MV, Ki KK, Redd MA, Bartnikowski N, et al. Administration of mesenchymal stem cells during ECMO results in a rapid decline in oxygenator performance. Thorax. 2019;74(2):194-6.

Mokhber-Dezfouli MR, Jabbari Fakhr M, Sadeghian Chaleshtori $\mathrm{S}$, et al. Intrapulmonary autologous transplant of bone marrow-derived mesenchymal stromal cells improves lipopolysaccharide-induced acute respiratory distress syndrome in rabbit. Crit Care. 2018;22(1):353.

Monsel A, Zhu YG, Gennai S, Hao Q, Hu S, Rouby JJ, et al. Therapeutic effects on human mesenchymal stem cellderived microvesicles in severe pneumonia in mice. Am J Respir Crit Care Med. 2015;192(3):324-36.

Németh K, Leelahavanichkul A, Yuen PS, et al. Bone marrow stromal cells attenuate sepsis via prostaglandin E(2)-dependent reprogramming of host macrophages to increase their interleukin-10 production. Nat Med. 2009;15(1):42-9. 
Nora CC, Camassola M, Bellagamba B, et al. Molecular analysis of the differentiation potential of murine mesenchymal stem cells from tissues of endodermal or mesodermal origin. Stem Cells Dev. 2012;21(10):1761-8.

Nystedt J, Anderson H, Tikkanen J, Pietilä M, Hirvonen T, Takalo $\mathrm{R}$, et al. Cell surface structures influence lung clearance rate of systemically infused mesenchymal stromal cells. Stem Cells. 2013;31(2):317-26.

Ortiz LA, Dutreil M, Fattman C, et al. Interleukin 1 receptor antagonist mediates the anti-inflammatory and antifibrotic effect of mesenchymal stem cells during lung injury. Proc Natl Acad Sci U S A. 2007;104(26):11002-7.

Ostanin AA, Petrovskii YL, Shevela EY, Chernykh ER. Multiplex analysis of cytokines, chemokines, growth factors, MMP-9 and TIMP-1 produced by human bone marrow, adipose tissue, and placental mesenchymal stromal cells. Bull Exp Biol Med. 2011;151(1):133-41.

Papazian L, Aubron C, Brochard L, Chiche JD, Combes A, Dreyfuss D, et al. Formal guidelines: management of acute respiratory distress syndrome. Ann Intensive Care. 2019;9(1):69.

Pati S, Khakoo AY, Zhao J, Jimenez F, Gerber MH, Harting M, et al. Human mesenchymal stem cells inhibit vascular permeability by modulating vascular endothelial cadherin $/ \beta$ catenin signaling. Stem Cells Dev. 2011a;20(1):89-101.

Pati S, Gerber MH, Menge TD, Wataha KA, Zhao Y, Baumgartner JA, et al. Bone marrow derived mesenchymal stem cells inhibit inflammation and preserve vascular endothelial integrity in the lungs after hemorrhagic shock. PLoS One. 2011b;6(9):e25171.

Pedrazza L, Lunardelli A, Luft C, Cruz CU, de Mesquita FC, Bitencourt S, et al. Mesenchymal stem cells decrease splenocytes apoptosis in a sepsis experimental model. Inflamm Res. 2014;63(9):719-28.

Pedrazza L, Cunha AA, Luft C, Nunes NK, Schimitz F, Gassen $\mathrm{RB}$, et al. Mesenchymal stem cells improves survival in LPSinduced acute lung injury through inhibition of NET formation. J Cell Physiol. 2017;232(12):3552-64.

Poggio HA, Antunes MA, Rocha NN, Kitoko JZ, Morales MM, Olsen PC, et al. Impact of one versus two doses of mesenchymal stromal cells on lung and cardiovascular repair in experimental emphysema. Stem Cell Res Ther. 2018;9(1): 296.

Qian J, Hu Y, Zhao L, Xia J, Li C, Shi L, et al. Protective role of adipose-derived stem cells in Staphylococcus aureus-induced lung injury is mediated by RegIII $\gamma$ secretion. Stem Cells. 2016;34(7):1947-56.

Raffaghello L, Bianchi G, Bertolotto M, Montecucco F, Busca A, Dallegri F, et al. Human mesenchymal stem cells inhibit neutrophil apoptosis: a model for neutrophil preservation in the bone marrow niche. Stem Cells. 2008;26(1):151-62.

Sepúlveda JC, Tomé M, Fernández ME, et al. Cell senescence abrogates the therapeutic potential of human mesenchymal stem cells in the lethal endotoxemia model. Stem Cells. 2014;32(7):1865-77.

Silva JD, de Castro LL, Braga CL, et al. Mesenchymal stromal cells are more effective than their extracellular vesicles at reducing lung injury regardless of acute respiratory distress syndrome etiology. Stem Cells Int. 2019a;2019:8262849.

Silva JD, Lopes-Pacheco M, Paz AHR, Cruz FF, Melo EB, de Oliveira MV, et al. Mesenchymal stem cells from bone marrow, adipose tissue, and lung tissue differentially mitigate lung and distal organ damage in experimental acute respiratory distress syndrome. Crit Care Med. 2018a;46(2):e132-40.

Silva JD, Lopes-Pacheco M, de Castro LL, et al. Eicosapentaenoic acid potentiates the therapeutic effects of adipose tissuederived mesenchymal stromal cells on lung and distal organ injury in experimental sepsis. Stem Cell Res Ther. 2019b;10(1):264.

Silva JD, Paredes BD, Araújo IM, Lopes-Pacheco M, Oliveira MV, Suhett GD, et al. Effects of bone marrow-derived mononuclear cells from healthy or acute respiratory distress syndrome donors on recipient lung-injured mice. Crit Care Med. 2014;42(7): e510-24.

Silva LHA, Antunes MA, dos Santos CC, et al. Strategies to improve the therapeutic effects of mesenchymal stromal cells in respiratory diseases. Stem Cell Res Ther. 2018b;9(1):45.

Simonson OE, Moudiakakos D, Heldring N, et al. In vivo effects of mesenchymal stromal cells in two patients with severe acute respiratory distress syndrome. Stem Cells Transl Med. 2015;4(10):1199-213.

Sun J, Han ZB, Liao W, Yang SG, Yang ZX, Yu JX, et al. Intrapulmonary delivery of human umbilical cord mesenchymal stem cells attenuates acute lung injury by expanding CD4+CD25+ Forkhead Boxp3 (FOXP3)+ regulatory T cells and balancing anti and pro-inflammatory factors. Cell Physiol Biochem. 2011;27(5):587-96.

Sung DK, Chang YS, Sung SI, Yoo HS, Ahn SY, Park WS. Antibacterial effect of mesenchymal stem cells against Escherichia coli is mediated by secretion of beta-defensin-2 via toll-like receptor 4 signalling. Cell Microbiol. 2016;18(3): 424-36.

Vasandan AB, Jahnavi S, Shashank C, Prasad P, Kumar A, Prasanna SJ. Human mesenchymal stem cells program macrophage plasticity by altering their metabolic status via a PGE $_{2}$-dependent mechanism. Sci Rep. 2016;6:38308.

Wang Y, Tan L, Jin J, Sun H, Chen Z, Tan X, et al. Non-cultured dermal-derived mesenchymal cells attenuate sepsis induced by cecal ligation and puncture in mice. Sci Rep. 2015;5: 16973.

Wang S, Mo M, Wang J, Sadia S, Shi B, Fu X, et al. Plateletderived growth factor receptor beta identifies mesenchymal stem cells with enhanced engraftment to tissue injury and pro-angiogenic property. Cell Mol Life Sci. 2018a;75(3): 547-61.

Wang C, Lv D, Zhang X, Ni ZA, Sun X, Zhu C. Interleukin-10overexpressing mesenchymal stromal cells induce a series of regulatory effects in the inflammatory system and promote the survival of endotoxin-induced acute lung injury in mice model. DNA Cell Biol. 2018b;37(1):53-61.

Wang L, Shi M, Tong L, Wang J, Ji S, Bi J, et al. Lung-resident mesenchymal stem cells promote repair of LPS-induced acute lung injury via regulating the balance of regulatory $\mathrm{T}$ cells and Th17 cells. Inflammation. 2019;42(1):199-210.

Weil BR, Herrmann JL, Abarbanell AM, Manukyan MC, Poynter JA, Meldrum DR. Intravenous infusion of mesenchymal stem cells is associated with improved myocardial function during endotoxemia. Shock. 2011;36(3):235-41.

Weiss DJ, Bertoncello I, Borok Z, Kim C, Panoskaltsis-Mortari A, Reynolds S, et al. Stem cells and cell therapies in lung biology and lung diseases. Proc Am Thorac Soc. 2011;8(3): 223-72. 
Wilson JG, Liu KD, Zhuo H, Caballero L, McMillan M, Fang X, et al. Mesenchymal stem (stromal) cells for treatment of ARDS: a phase 1 clinical trial. Lancet Respir Med. 2015;3(1):24-32.

Xiang B, Chen L, Wang X, Zhao Y, Wang Y, Xiang C. Transplantation of menstrual blood-derived mesenchymal stem cells promotes the repair of LPS-induced acute lung injury. Int J Mol Sci. 2017;18(4). https://doi.org/10.3390 /ijms18040689.

Yáñez-Mó M, Siljander PR-M, Andreu Z, et al. Biological properties of extracellular vesicles and their physiological functions. J Extracell Vesicles. 2015;4:1-60.

Yang Y, Hu S, Xu X, et al. The vascular endothelial growth factorexpressing character of mesenchymal stem cells plays a positive role in treatment of acute lung injury in vivo. Mediat Inflamm. 2016;2016:2347938.

Zhang X, Wang H, Shi Y, Peng W, Zhang S, Zhang W, et al. Role of bone marrow-derived mesenchymal stem cells in the prevention of hyperoxia-induced lung injury in newborn mice. Cell Biol Int. 2012;36(6):589-94.

Zhang Z, Li W, Heng Z, et al. Combination therapy of human umbilical cord mesenchymal stem cells and FTY720 attenuates acute lung injury induced by lipopolysaccharide in a murine model. Oncotarget. 2017;8(44):77407-14. https://doi.org/10.18632/oncotarget.20491.
Zhang S, Jiang W, Ma L, Liu Y, Zhang X, Wang S. Nrf2 transfection enhances the efficacy of human amniotic mesenchymal stem cells to repair lung injury induced by lipopolysaccharide. J Cell Biochem. 2018;119(2):1627-36.

Zhang X, Chen J, Xue M, Tang Y, Xu J, Liu L, et al. Overexpressing p130/E2F4 in mesenchymal stem cells facilitates the repair of injured alveolar epithelial cells in LPSinduced ARDS mice. Stem Cell Res Ther. 2019;10(1):74.

Zhao Y, Yang C, Wang H, Li H, du J, Gu W, et al. Therapeutic effects of bone marrow-derived mesenchymal stem cells on pulmonary impact injury complicated with endotoxemia in rats. Int Immunopharmacol. 2013;15(2):246-53.

Zhao X, Liu D, Gong W, Zhao G, Liu L, Yang L, et al. The toll-like receptor 3 ligand, poly(I:C) improves immunosuppressive function and therapeutic effect of mesenchymal stem cells on sepsis via inhibiting MiR-143. Stem Cells. 2014;32(2):521-33.

Zheng G, Huand L, Tong H, et al. Treatment of acute respiratory distress syndrome with allogeneic adipose-derived mesenchymal stem cells: a randomized, placebo-controlled pilot study. Respir Res. 2014;15:39.

Publisher's note Springer Nature remains neutral with regard to jurisdictional claims in published maps and institutional affiliations. 